\title{
CCR5 deficiency accelerates lipopolysaccharide-induced astrogliosis, amyloid-beta deposit and impaired memory function
}

\author{
Chul Ju Hwang ${ }^{1, *}$, Mi Hee Park ${ }^{1, *}$, Jae Yeon Hwang1, Ju Hwan Kim¹, Na Young Yun ${ }^{1}$, \\ Sang Yeon Oh${ }^{1}$, Ju Kyung Song ${ }^{1}$, Hyun Ok Seo ${ }^{1}$, Yun-Bae Kim², Dae Yeon Hwang ${ }^{3}$, \\ Ki-Wan Oh ${ }^{1}$, Sang-Bae Han ${ }^{1}$ and Jin Tae Hong ${ }^{1}$ \\ ${ }^{1}$ College of Pharmacy and Medical Research Center, Chungbuk National University, Cheongju, Republic of Korea \\ ${ }^{2}$ College of Veterinary Medicine, Chungbuk National University, Cheongju, Republic of Korea \\ ${ }^{3}$ College of Natural Resources and Life Science, Pusan National University, Pusan, Republic of Korea \\ * These authors have contributed equally to this work \\ Correspondence to: Jin Tae Hong, email: jinthong@chungbuk.ac.kr \\ Keywords: Alzheimer's disease (AD), Amyloid beta (Aß), CC chemokine receptor 2 (CCR2), CC chemokine receptor 5 (CCR5), \\ memory impairment, Pathology Section \\ Received: August 30, $2015 \quad$ Accepted: February 05, $2016 \quad$ Published: February 17, 2016
}

\section{ABSTRACT}

Chemokine receptors are implicated in inflammation and immune responses. Neuro-inflammation is associated with activation of astrocyte and amyloid-beta $(A \beta)$ generations that lead to pathogenesis of Alzheimer disease (AD). Previous our study showed that deficiency of CC chemokine receptor 5 (CCR5) results in activation of astrocytes and $A \beta$ deposit, and thus memory dysfunction through increase of $C C$ chemokine receptor 2 (CCR2) expression. CCR5 knockout mice were used as an animal model with memory dysfunction. For the purpose LPS was injected i.p. daily $(0.25 \mathrm{mg} /$ $\mathrm{kg} /$ day). The memory dysfunctions were much higher in LPS-injected CCR5 knockout mice compared to CCR5 wild type mice as well as non-injected CCR5 knockout mice. Associated with severe memory dysfuction in LPS injected CCR5 knockout mice, LPS injection significant increase expression of inflammatory proteins, astrocyte activation, expressions of $\beta$-secretase as well as A $\beta$ deposition in the brain of CCR5 knockout mice as compared with that of CCR5 wild type mice. In CCR5 knockout mice, CCR2 expressions were high and co-localized with GFAP which was significantly elevated by LPS. Expression of monocyte chemoattractant protein-1 (MCP-1) which ligands of CCR2 also increased by LPS injection, and increment of MCP-1 expression is much higher in CCR5 knockout mice. BV-2 cells treated with CCR5 antagonist, D-alapeptide T-amide (DAPTA) and cultured astrocytes isolated from CCR5 knockout mice treated with LPS $(1 \mu \mathrm{g} / \mathrm{ml})$ and CCR2 antagonist, decreased the NF-KB activation and $A \beta$ level. These findings suggest that the deficiency of CCR5 enhances response of LPS, which accelerates to neuro-inflammation and memory impairment.

\section{INTRODUCTION}

Pathological features that appear in the brain of $\mathrm{AD}$ patients include deposition of amyloid plaques, neuronal and synaptic loss and activation of astrocytes [1-5]. Activated astrocytes could be implicated in accumulation of amyloid-beta $(A \beta)$, a principal component of senile plaque in Ad brain [6,7]. Recent data also indicated that astrocytes may act as a source for $A \beta$ because they overexpress $\beta$-secretase (BACE1), an enzyme that cleaves amyloid precursor protein (APP) to produce $A \beta[8]$. These studies suggest that activated astrocytes contribute to the synthesis of $A \beta$ and progress of $A D$.

Chemokines are produced upon activation by a wide 
spectrum of inflammatory cell types including astrocytes $[9,10]$. Several chemokines, and their receptors and ligands have been found to be upregulated in the AD brain [11]. Monocyte chemoattractant protein 1 (MCP-1), ligand of CC chemokine receptor 2 (CCR2), is found in senile plaque and reactive microglia [12] and promotes activation of astrocytes [13]. It was suggested that neuroinflammation was extended by chemokine-mediated microglial activation and recruitment of astrocytes to the area of neuroinflammation $[14,15]$. We previously found that CCR5 deficiency activated astrocytes and $\mathrm{A} \beta$ accumulation via upregulation of CCR2 [16]. These findings suggest that chemokines, and their receptors and ligands may contribute to the development and/or the progression of $\mathrm{AD}$ through modification of astrocyte activation.

It has been continuously reported that brain and systemic LPS injection cause neuroinflammation and thus causing $A \beta$ deposition and memory dysfunction $[17$, 18]. CCRs expression was induced in the microglia after treatment with LPS $[19,20]$. Moreover, CCR5 suppressed LPS-induced microglial neurotoxicity [21] and expression of metalloproteinases (MMPs), important mediators of neuroinflammation in astrocytes [22]. Thus in the present study, we investigated how CCR5 deficiency affects LPSinduced activation of astocytes and its relevance to $\mathrm{A} \beta$ accumulation in the neuroinflammatory condition of $\mathrm{AD}$ pathogenesis.

\section{RESULTS}

\section{Accelerated effect of CCR5 knockout on the inflammation-induced memorial impairments in CCR5 mice}

The water maze test is a widely accepted method of memory testing, and can evaluate spatial learning and memory. Therefore, the Morris water maze was used to determine whether lack of CCR5 influenced spatial learning and memory function. The ability of mice to acquire and recall spatial information was assessed by escape latency in the Morris water maze. The LPS-injected $\mathrm{CCR}^{+/+}$and LPS-injected $\mathrm{CCR}^{-/}$mice exhibited a reduction in escape latency over the training period, but
A

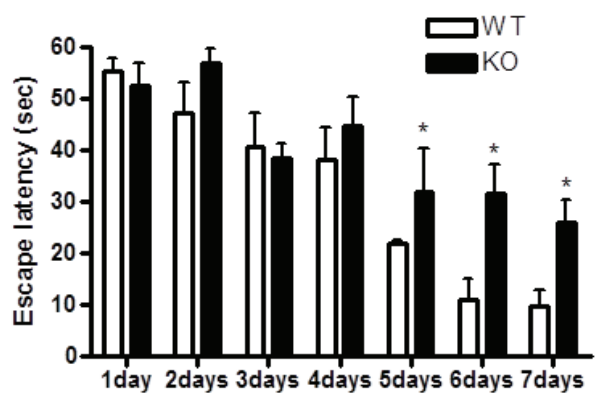

B

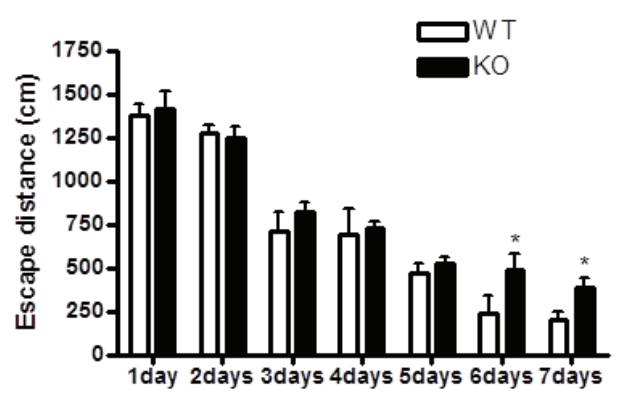

Figure 1: Difference in memory function between $\mathrm{CCR5}^{+/+}$and $\mathrm{CCR5}^{-/-}$mice in water maze test and passive avoidance. $\mathrm{CCR}^{+/+}$and $\mathrm{CCR} 5^{-/}$mice were evaluated for learning and memory of spatial information using the water maze. On days 1-8, each mouse received three training trials in which the mouse was allowed to swim freely about a pool in which a submerged, hidden platform was located. Escape latency, the time required to find the platform A. and swimming distance, the distance swam to find the platform B. were measured, and after the water maze test, probe trials to measure maintenance of memory were performed $\mathbf{C}$. Mice were permitted to swim for a maximum of $60 \mathrm{sec}(n=7)$. A passive avoidance test was performed by step-through methods D. Once a mouse enters completely into the dark compartment, it receives an electric shock $(0.5 \mathrm{~mA}, 3 \mathrm{sec})$ through the stainless steel grid floor. The bar indicates the mean latencies to enter the dark compartment on the learning trial (2 days and 3days) and $24 \mathrm{hr}$ and $48 \mathrm{hr}$ later on the testing trial (1 day). The step-through latency was expressed as mean \pm S.E.M $(n=7)$ and the maximum recording time is 300 sec per trial. *Significant difference between $\mathrm{CCR} 5^{+/+}$mice $(P<0.05)$. 
escape latency of LPS-injected CCR $5^{-/-}$mice was slower than that of LPS-injected $\mathrm{CCR}^{+/+}$mice (Figure 1A). The escape distance on day 5 to 7 (which may correspond the time to gain completed memory function) was significantly longer in LPS-injected $\mathrm{CCR}^{-/}$mice than that of LPS-injected $\mathrm{CCR} 5^{+/+}$mice. Swimming distance of LPS-injected CCR5 $5^{-/}$mice was similar to that of LPSinjected $\mathrm{CCR}^{+/+}$mice until day 4 , but was significantly longer than that of LPS-injected $\mathrm{CCR}^{+/+}$mice after day 5 (Figure 1B). Compared to LPS non injected mice [16], escape latency and distance were much higher after LPS injection in both $\mathrm{CCR}^{+/+}$and $\mathrm{CCR}^{-/}$mice. In our previous study showed that the memory impairment were higher in $\mathrm{CCR}^{-/-}$mice than $\mathrm{CCR}^{+/+}$mice [16]. However, there is more severe memory impairment then previous data (LPS non-injection group) when after LPS injection in present study (Supplementary Table 1). These results indicate that the ability of acquisition and recalling of memory was lowered by LPS-injection, and the memory impairment was higher in LPS-injected $\mathrm{CCR}^{-/-}$mice compared with that of LPS-injected $\mathrm{CCR} 5^{+/+}$mice.

After the water maze test, we performed a probe test to investigate maintenance of memory. The time spent in the target area by LPS-injected $\mathrm{CCR}^{-/-}$mice compared with the LPS-injected $\mathrm{CCR} 5^{+/+}$mice during the probe test. Probe test of the LPS-injected $\mathrm{CCR} 5^{-/}$mice group was shorter than that of the LPS-injected $\mathrm{CCR}^{+/+}$mice group (Figure 1C), suggesting that LPS-injected $\mathrm{CCR}^{-/-}$mice were more severe in memory maintenance than $\mathrm{CCR}^{+/+}$ mice. Compared to LPS non-injected CCR5 $5^{-/-}$mice [16], LPS-injected $\mathrm{CCR}^{\%}$ mice showed greater memory dysfunction.

To investigate the role of CCR5 in memory function, we compared the memory behavior between $\mathrm{CCR}^{+/+}$ and $\mathrm{CCR}^{-/}$mice. Passive avoidance test was performed to test long-term memory function using a step-through protocol. On learning day, animals entered the dark compartment, but the step-through latency of $\mathrm{CCR} 5^{-/-}$mice was higher even though learning trials. However, during the testing day, there was no significant difference in time entering the dark compartment (the time maintaining memory function) between $\mathrm{CCR}^{+/+}$and $\mathrm{CCR}^{-/-}$mice. The day after testing day, difference of latency was still no significance (Figure 1D). The results of the passive avoidance test could not explain the memory impairment between two groups. However, when we perform the test
A
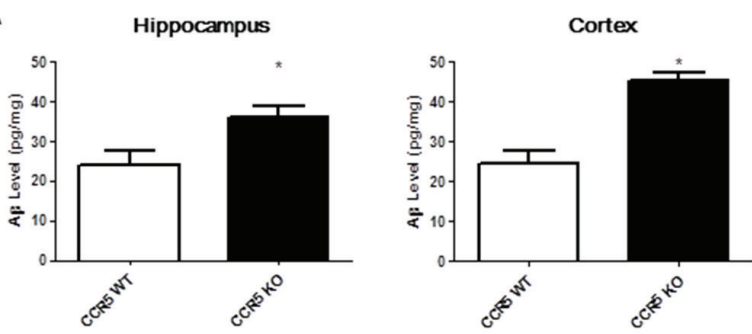

B

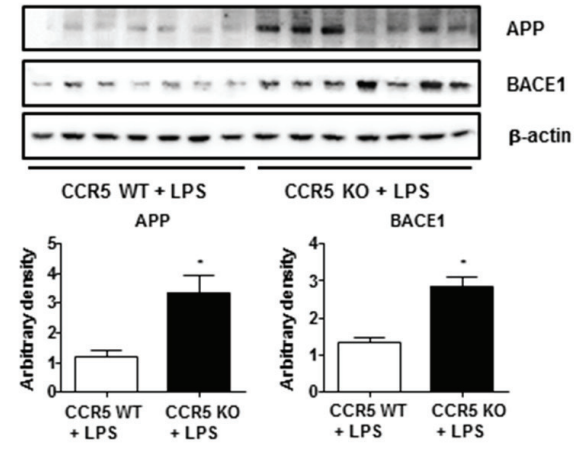

D

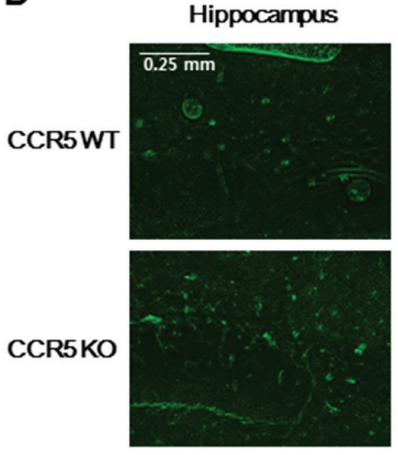

Cortex

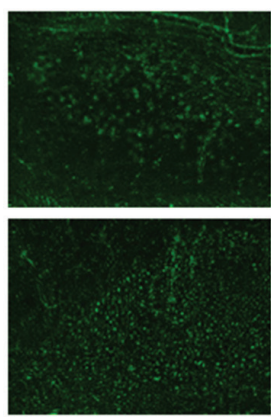

Figure 2: Level of $A \beta_{1-42}$ and amyloidogenesis related proteins (BACE1 and APP) in the brains of CCR5 ${ }^{+/+}$and $\mathrm{CCR5}^{-}$ ${ }^{1-}$ mice. The amounts of $A \beta_{1-42}$ were assessed by using a specific $A \beta_{1-42}$ ELISA kit as described in the materials and method section A. The experiment was performed using hippocampus and cortex regions. Expression of amyloidogenesis related protein (BACE1 and APP) in the brains of $\mathrm{CCR}^{+/+}$and CCR5 ${ }^{-/}$mice. The expression of BACE1 and APP was detected by Western blotting using specific antibodies B. Immunostaining of $A \beta_{1-42}$ in the brains of $\mathrm{CCR}^{+/+}$and $\mathrm{CCR} 5^{-/-}$mice. $25 \mu \mathrm{m}$-thick brain sections were incubated with rabbit polyclonal anti-A $\beta_{1-42}$ antibody $\mathbf{C}$. Thioflavin $\mathrm{S}$ steining for detection of $\mathrm{A} \beta$ accumulation $\mathbf{D}$. The distribution of amyloid plaques is shown in the brains of $\mathrm{CCR} 5^{-/}$mice compared with those of $\mathrm{CCR}^{+/+}$mice. Values measured from each group of mice were calibrated by amount of protein and data are expressed as mean \pm S.E.M $(n=7)$. *Significant difference between CCR $5^{+/+}$mice $(P<0.05)$. 
with LPS injected mice; we found that behavior activity was lower than LPS non injected mice in other study. Also, recent study demonstrated that mice treated with LPS were significantly less active and moved more slowly [23]. So we performed locomotor test for check difference of activity between $\mathrm{CCR}^{+/+}$and $\mathrm{CCR}^{-/-}$mice.

To check the difference of activity between $\mathrm{CCR}^{+/+}$ and $\mathrm{CCR}^{-/}$mice, we compared the behavior activity by open field test and locomotor activity test between $\mathrm{CCR} 5^{+/+}$ and $\mathrm{CCR}^{-/-}$mice. In open field test, the total distance was significantly decreased in $\mathrm{CCR} 5^{-/}$mice after LPS injected (Supplementary Figure 1A). Duration of entering into a central square was also decreased in LPS injected $\mathrm{CCR}^{-/-}$mice (Supplementary Figure 1B). Additionally, in locomotor activity test which measured with a tilting-type ambulometer was significantly decreased in LPS injected $\mathrm{CCR}^{-/}$mice (Supplementary Figure 1C). These data suggest that reason of no difference in passive avoidance test between two groups may be not memory impairment but physical activity by LPS treatment.

\section{Enhancement effect of CCR5 knockout on the LPS-induced amyloidogenesis in the CCR5 mice brain}

To investigate whether memory impairment in LPSinjected $\mathrm{CCR}^{-/-}$mice is related with the accumulation of $A \beta_{1-42}$, we measured $A \beta_{1-42}$ level in the brains of LPS-injected $\mathrm{CCR}^{+/+}$and LPS-injected $\mathrm{CCR}^{-/-}$mice. The levels of $\mathrm{A} \beta_{1-42}$ in LPS-injected $\mathrm{CCR}^{-/-}$mice were significantly higher than that of LPS-injected CCR5 $5^{+/+}$ mice in hippocampus and cortex regions (Figure 2A). To investigate whether absence of CCR5 influences amyloidogenesis in the brain, we performed Western blot assay to detect the expression pattern of $\beta$-secretase (BACE1) and APP of LPS-injected $\mathrm{CCR}^{+/+}$and LPSinjected $\mathrm{CCR}^{-/}$mice. Expression of BACE1, a key enzyme to generate $A \beta_{1-42}$, was signiticantly higher in the brains of $\mathrm{CCR}^{-/-}$mice than those of LPS-injected $\mathrm{CCR}^{+/+}$mice. Expression of APP was also significantly higher in the brains of LPS-injected $\mathrm{CCR} 5^{-/}$mice than those of LPS-injected $\mathrm{CCR} 5^{+/+}$mice (Figure 2B). A $\beta_{1 \text {. }}$ ${ }_{42}$ immunoreactivity had perinuclear localization in the cortex, and had a granular pattern in the hippocampus of LPS-injected $\mathrm{CCR}^{-/}$mice. The immunohistochemical analysis by $A \beta_{1-42}$ specific antibody has shown the $A \beta$ deposition in the brain of LPS-injected CCR5 $5^{-/}$mice compared with LPS-injected $\mathrm{CCR}^{+/+}$mice (Figure 2C). In Thioflavin $\mathrm{S}$ staining, $\mathrm{A} \beta_{1-42}$ was increased in the brains of LPS-injected CCR5 $5^{-/}$mice compared with LPS-injected $\mathrm{CCR}^{+/+}$mice (Figure 2D). These results indicate that the increased level of $\mathrm{A} \beta_{1-42}$ in the brain and the memory impairment of LPS-injected $\mathrm{CCR}^{-/-}$mice are closely related. In our previous study showed that the increased levels of $\mathrm{A} \beta_{1-42}$ close to $120 \%$ higher than $\mathrm{CCR}^{+/+}$mice in
$\mathrm{CCR}^{-/-}$mice [16]. However, there is much higher increase (about $170 \%$ ) of $\mathrm{A} \beta_{1-42}$ levels in $\mathrm{CCR} 5^{-/-}$mice compared to $\mathrm{CCR}^{+/+}$mice after LPS injection in present study.

Compared to LPS non-injected mice [16], LPS injected mice showed much higher amyloidogenesis as well as neuroinflammation. These evidence suggests that CCR5 knockout accelerated LPS induced amyloidogenesis in $\mathrm{CCR}^{-/-}$mice brain.

\section{Enhancement effect of CCR5 knockout on the LPS-induced expression of inflammation related proteins in the CCR5 mice brain}

We previously find that neuroinflammation is critical for $A \beta$ generation, and astrocytes are important contributing factor about neuroinflammation and amyloidogenesis in neuronal cells. We used the methods of Western blot and immunohistochemistry to detect the expression of COX-2 and iNOS in mouse brains. Our data indicate that LPS-injected $\mathrm{CCR}^{-/}$mice were significantly increased of these proteins in hippocampus when compared with LPS-injected $\mathrm{CCR}^{+/+}$mice. Immunostaining for COX-2 and iNOS (Figure 3A) showed significantly higher number of COX-2 and iNOS reactive cells in LPS-injected CCR5 $5^{-/}$mice brain compared to the number in LPS-injected $\mathrm{CCR} 5^{+/+}$mice brain.

Since activation of astrocytes and microglia in the brain has been known to be critical in the accumulation of $\mathrm{A} \beta$, brain tissues from LPS-injected $\mathrm{CCR}^{+/+}$and LPS-injected $\mathrm{CCR}^{-/}$mice were stained with glial fibrillary acidic protein (GFAP), a marker protein of astrocytes, to assess astrocytes architecture. GFAP immunohistochemistry revealed a global increase in GFAP immunoreactivity in the brains of LPS-injected CCR5/. mice as compared with LPS-injected CCR5 $5^{+/+}$mice. GFAP-positive cells in the brains of LPS-injected CCR5 / mice were frequently hypertrophied in comparison to those in LPS-injected $\mathrm{CCR}^{+/+}$brains (Figure 3A). The numbers of reactive cells of immunostaining for iBA1 (a marker protein of microglia cells) in hippocampus of LPS-injected $\mathrm{CCR}^{-/}$mice were also significantly higher compared to the numbers in LPS-injected CCR $5^{+/+}$(Figure 3A).

Paralleled with the immunostaining data, the results of Western blot also showed that expression of COX-2, iNOS, GFAP and iBA1 were also higher in the brains of LPS-injected CCR5 $5^{-/}$mice compared with LPS-injected $\mathrm{CCR}^{+/+}$mice detected by Western blot (Figure 3B).

These results suggest that astrocytes were greatly activated in the brains of LPS-injected $\mathrm{CCR}^{-/-}$mice compared to that of $\mathrm{CCR} 5^{+/+}$mice brain. 


\section{Effect of CCR5 knockout on the expression of CCR2 in the brain}

Recent study has suggested that absence of CCR5 could induce the activation of CCR2, which leads to the activation of astrocytes. Thus, expression of CCR2 in the brains was performed by Western blot method. Expression of CCR2 in the brains of LPS-injected CCR5 1- mice was higher than that of LPS-injected $\mathrm{CCR} 5^{+/+}$ mice. Immunohistochemistry of CCR2 in the brains also showed that CCR2 was overexpressed in the neuronal cell membrane of LPS-injected CCR5 ${ }^{-/}$mice, whereas CCR2 was poorly expressed in the brains of LPSinjected CCR5 ${ }^{+/+}$mice (Figure 4A). Paralleled with the immunostaining data, the results of Western blot also showed that expression of CCR2 was also higher in the brains of LPS-injected $\mathrm{CCR} 5^{-/}$mice compared with LPSinjected $\mathrm{CCR}^{+/+}$mice detected by Western blot (Figure 4B). To demonstrate that CCR2 could be involved with activation of astrocytes, double immunofluorescence staining of GFAP and CCR2 was performed. Double immunofluorescence staining showed that signifcant higher immunoreactive cells against GFAP was observed in the brains of LPS-injected CCR $5^{-/}$mice than those of LPS-injected $\mathrm{CCR}^{+/+}$mice. In the brains of LPS-injected $\mathrm{CCR}^{+/+}$mice, CCR2 was normally expressed and a small number of cells were double positive for GFAP and CCR2 (Figure 4C). The results suggest that the absence of CCR5 leads to increased expression of CCR2, which in turn activates astrocytes and $\mathrm{A} \beta$ production via a compensative mechanism.

\section{Enhancement effect of CCR5 knockout on the LPS-induced MCP-1 levels in the CCR5 mice brain}

MCP-1 is one of the most important for neuroinflammation, NF-kB activation as well as
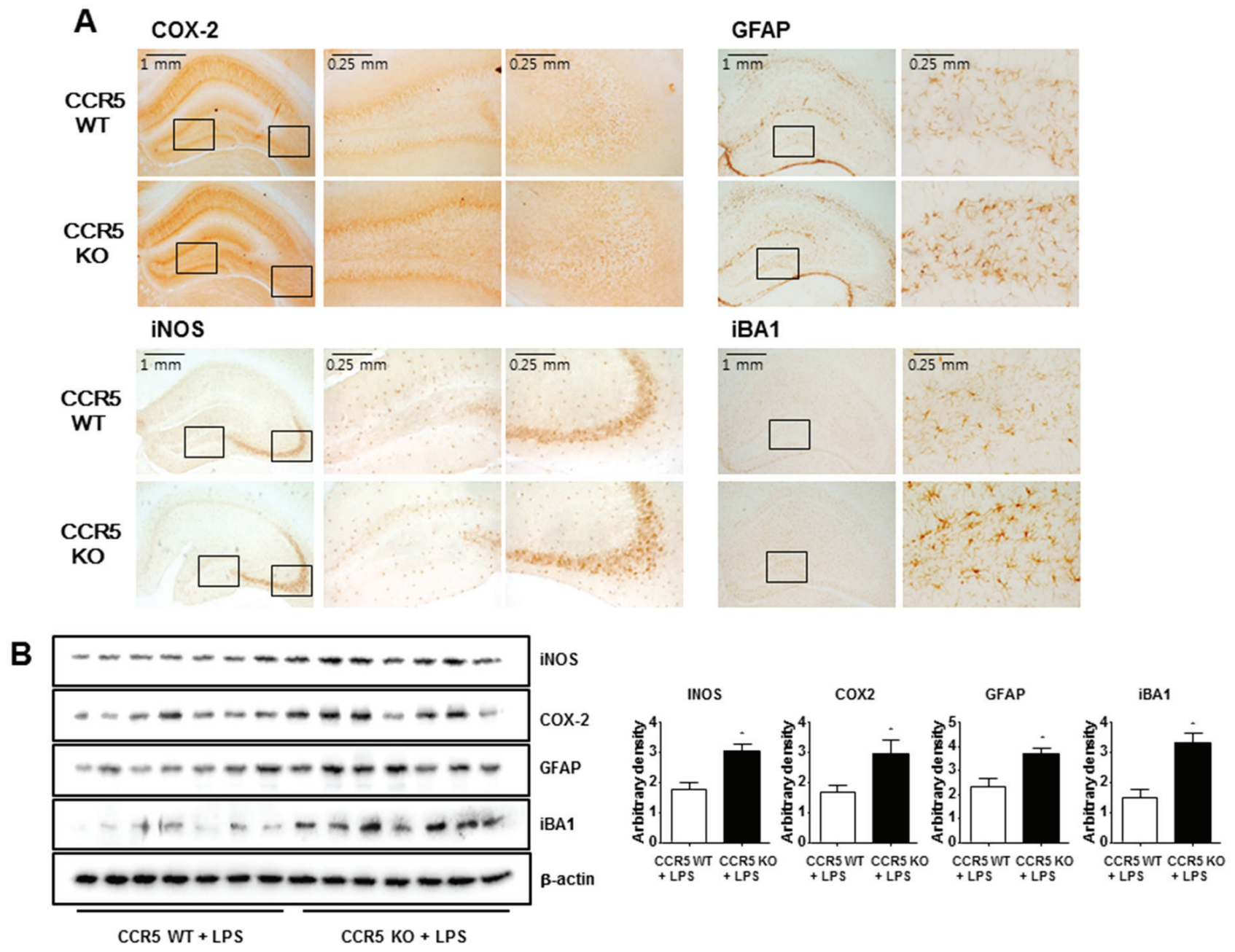

Figure 3: Expression of inflammatory proteins and activation of astrocytes and microglia cells in the brains of $\mathrm{CCR}^{+/+}$ and $\mathrm{CCR5}^{--}$mice. Brain sections and lysates were incubated with specific antibodies against COX-2, iNOS, GFAP and Iba1 proteins, and then were detected by immunohistochemistry A. and Western blot B. Data are expressed as mean \pm S.E.M $(n=7)$. *Significant difference between $\mathrm{CCR}^{+/+}$mice $(P<0.05)$. 
amyloidogenesis [8, 24, 25]. Our previous study shows that the absence of CCR5 can lead the increment of CCR2 expression [16]. Also, recent study revealed that chemokines such as MCP-1(CCL2) activate astrocytes via CCR2 [13]. To investigate whether neuroinflammation in LPS-injected $\mathrm{CCR}^{-/}$mice is related with the expression of MCP-1, we measured MCP-1 level in the brains of LPS-injected $\mathrm{CCR}^{+/+}$and LPS-injected $\mathrm{CCR}^{-/}$mice. LPS injection elevated MCP-1 level compared to nontreated group in both CCR5 wild and knockout mice. However, the levels of MCP-1 in LPS-injected CCR5 ${ }^{-1-}$ mice were significantly higher than that of LPS-injected $\mathrm{CCR}^{+/+}$mice in hippocampus (Figure 5A) and cortex (Figure 5B) regions.

\section{Effect of CCR5 knockout on the DNA binding activity of NF-kB in the brain}

The activation of NF- $\mathrm{KB}$ plays a critical role in the neuro-inflammation since it control several gens involving neuroinflammation as well as amyloidogenesis. To determine whether absence of CCR5 could increase the activation of NF-KB after LPS injection, we measured the DNA binding activity of NF-KB by EMSA, and translocations of p50 and p65 into nucleus and the protein expression were determined by Western blotting. Much higher DNA binding activity of NF-kB (Figure 5C) and the nuclear translocations of p50 and p65 (Figure
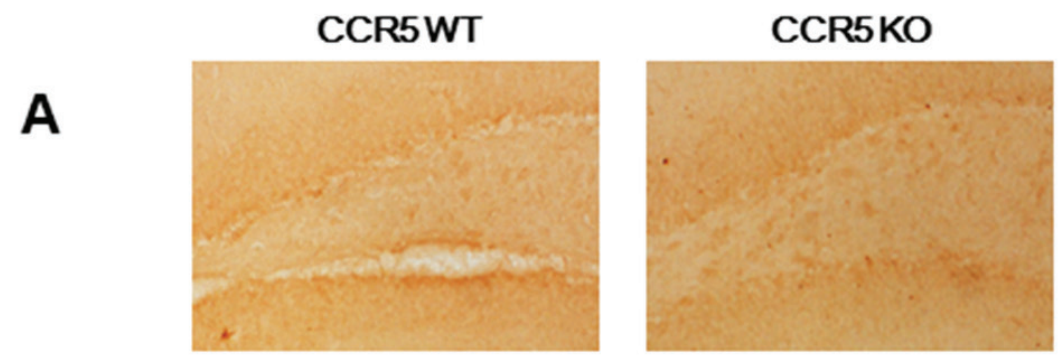

B
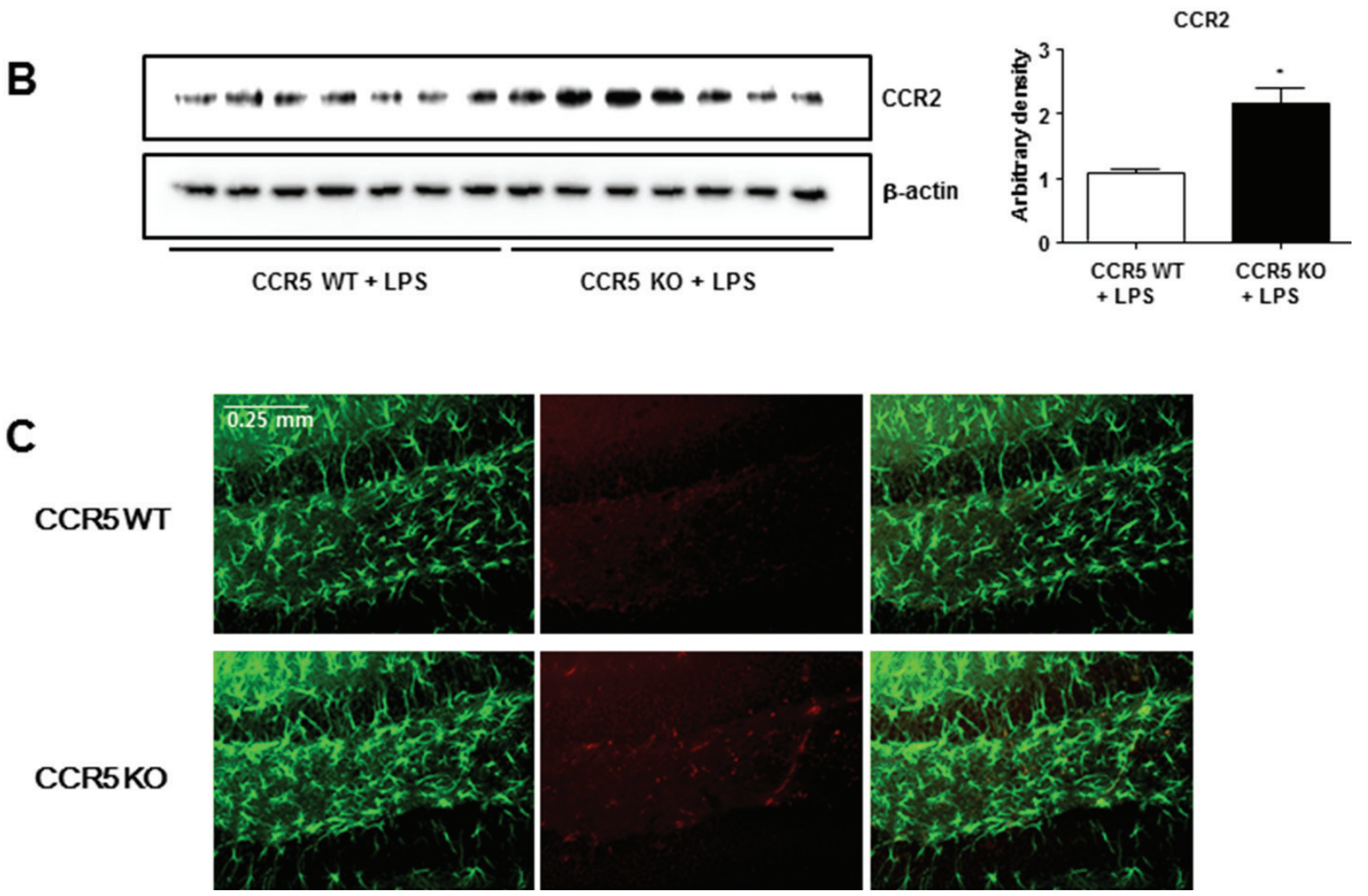

Figure 4: Expression of CCR2 in the brains of $\mathrm{CCR5}^{+/+}$and $\mathrm{CCR5}^{-/-}$mice. Brain sections and lysates were incubated with specific antibodies against CCR2 proteins, and then were detected by immunohistochemistry A. and Western blot B. To evaluate relation of CCR2 and astrocytes activation, double immunofluorescence staining of GFAP with CCR2 C. was performed. Brain sections were incubated with specific antibodies against GFAP (green) and CCR2 (red) proteins. Data are expressed as mean $\pm \operatorname{S.E.M~}(n=7)$. ${ }^{*}$ Significant difference between $\mathrm{CCR}^{+/+}$mice $(P<0.05)$. 
5D) were observed in the brain of $\mathrm{CCR} 5^{-/-}$compared to $\mathrm{CCR}^{+/+}$mice when after LPS injection.

\section{Involvement of CCR2 on activation of NF- $\mathrm{KB}, \mathrm{A} \beta$ accumulation and MCP-1 expression in microglia cells and cultured astrocytes isolated from CCR5 ${ }^{1-}$ mice}

To further demonstrate the involvement of CCR2 in CCR5-mediated amyloidogenesis NF-KB activation, $\mathrm{A} \beta$ accumulation and MCP-1 level were determined in astrocytes and microglia cells. We used BV-2 cells treated with CCR5 antagonist, D-ala-peptide T-amide (DAPTA) and cultured astrocytes isolated from $\mathrm{CCR}^{-/}$mice treated with LPS $(1 \mu \mathrm{g} / \mathrm{ml})$ and CCR2 antagonist (Santa Cruz Biotechn, Santa Cruz, CA, USA), and measured the DNA binding activity of NF-KB by EMSA. A $\beta$ accumulation was also determined by $A \beta$ specific ELISA kit. The treatment of CCR2 antagonist, decreased the DNA binding

A
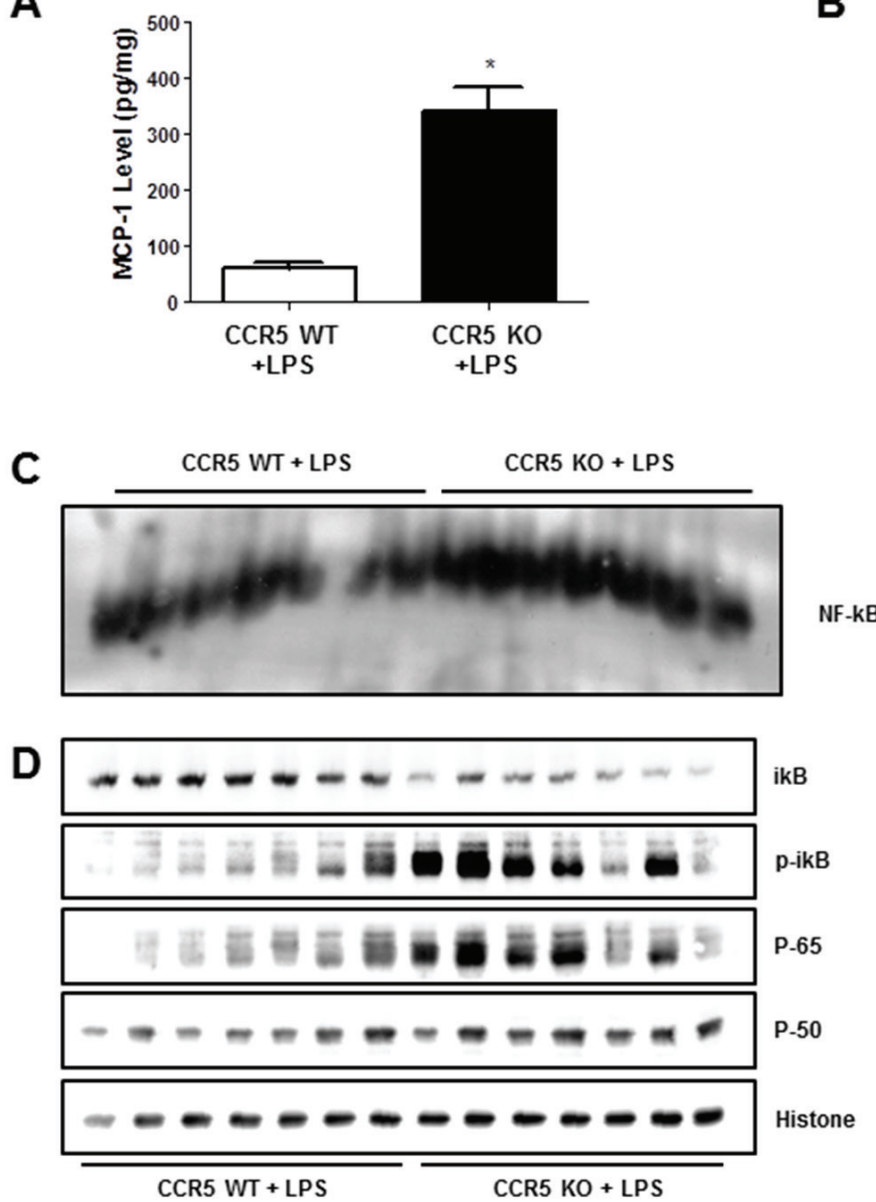

activity of NF-кB in DAPTA treated BV-2 cells (Figure $6 \mathrm{~A}$ ) and cultured astrocytes isolated from $\mathrm{CCR} 5^{-/}$mice (Figure 6B). A $\beta$ levels were also decreased after CCR2 antagonist treatment in DAPTA treated BV-2 cells (Figure 6C) and cultured astrocytes isolated from CCR $5^{-/}$mice (Figure 6D). Additionally, the level of MCP-1 protein was also determined by specific ELISA kit. However, MCP-1 levels were not changed by treatment of CCR2 antagonist in DAPTA treated BV-2 cells (Figure 6E) and cultured astrocytes isolated from CCR $5^{-/}$mice (Figure $6 \mathrm{~F}$ ). These data show that treatment of CCR2 antagonist could decrease NF-KB activity and amyloidogenesis through blocking to bind CCR2 and its ligand MCP-1.

\section{Effect of CCR5 knockout on cell death in CCR5 mice brain}

Activation of astrocytes could influence $A \beta$ accumulation which causes apoptotic neuronal cell death.

B
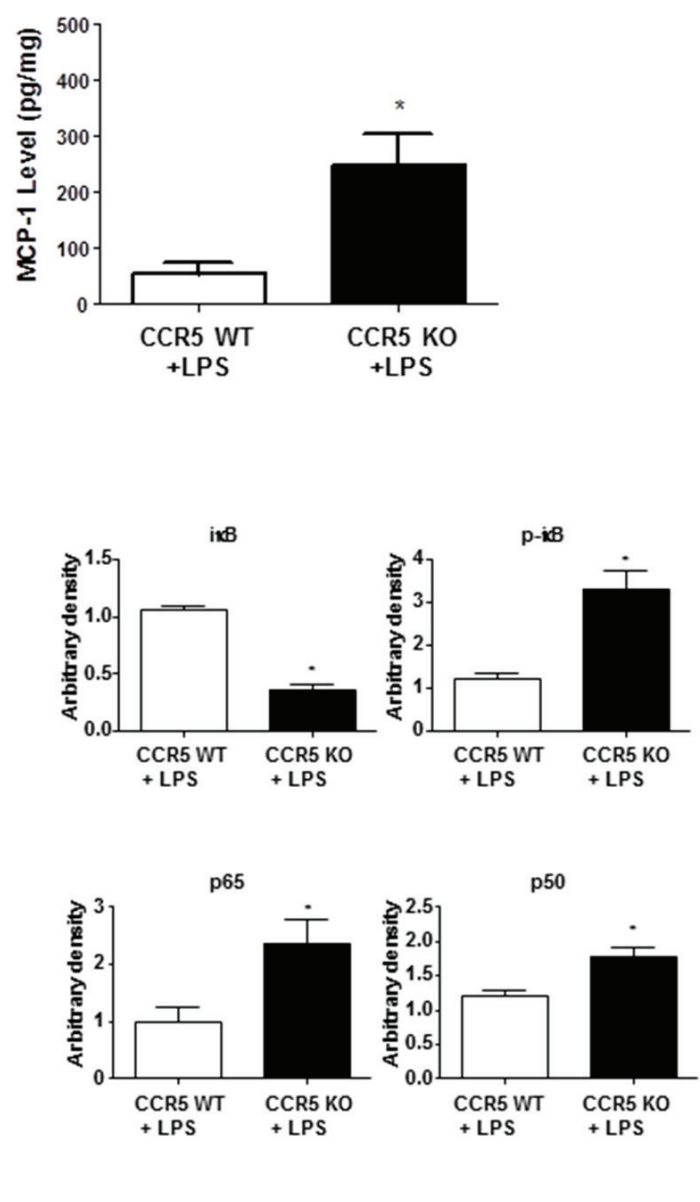

Figure 5: Level of MCP-1 and activation of NF-KB in the brains of CCR5 ${ }^{+/+}$and CCR5 ${ }^{-/-}$mice. The amounts of MCP-1 were assessed by using a specific MCP-1 ELISA kit as described in the materials and method section. The experiment was performed using hippocampus A. and cortex B. regions. DNA binding activity of NF-kB in $\mathrm{CCR}^{+/+}$and $\mathrm{CCR} 5^{-/-}$mice brain was determined by EMSA C. Expression of p50, p65, p-iкB and total iкB in $\mathrm{CCR}^{+/+}$and $\mathrm{CCR} 5^{-/-}$mice brain were determined by western blots $\mathbf{D}$. Values measured from each group of mice were calibrated by amount of protein and data are expressed as mean \pm S.E.M $(n=7)$. * Significant difference between $\mathrm{CCR}^{+/+}$mice $(P<0.05)$. 
To investigate apoptosis of neuronal cells in the brain, we performed TUNEL assay in brain sections. In the brains of LPS-injected CCR5 ${ }^{-/-}$mice, TUNEL-positive apoptotic cells were frequently observed and the indication of apoptosis was significantly higher in LPS-injected CCR5 $5^{-/}$ mice than that of $\mathrm{CCR}^{+/+}$mice (Supplementary Figure 2).

\section{DISCUSSION}

In the present study, it was shown that the deficiency of CCR5 in LPS treated CCR5 ${ }^{-/}$mice resulted in the dysfunction of memory capacity. Associated with the
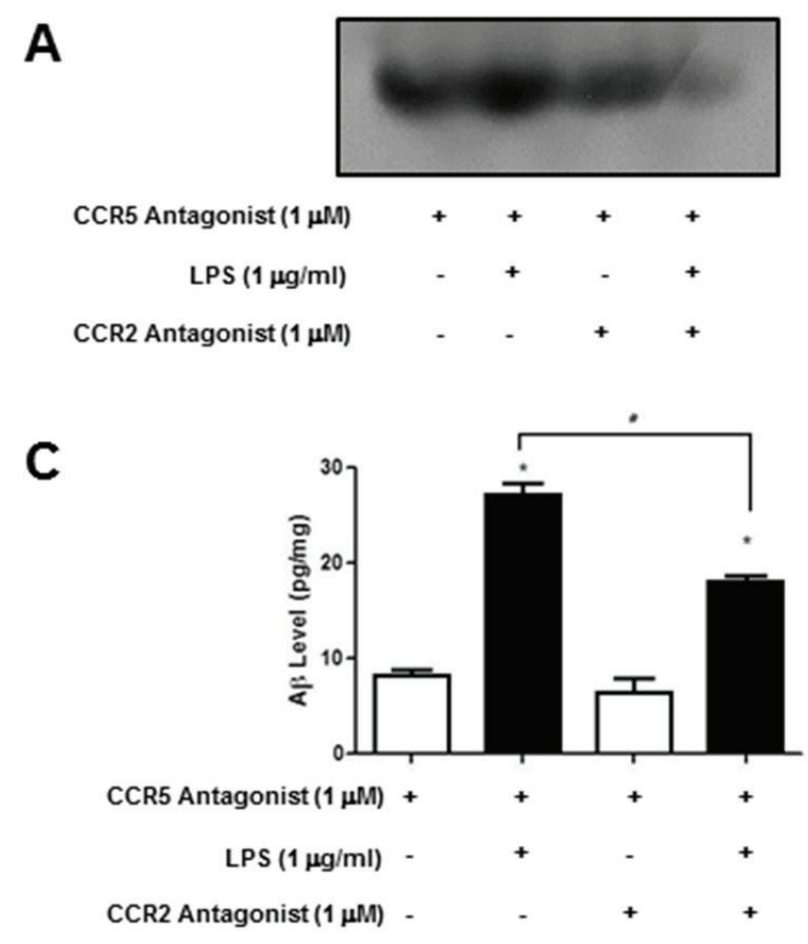

\section{$\mathbf{E}$}

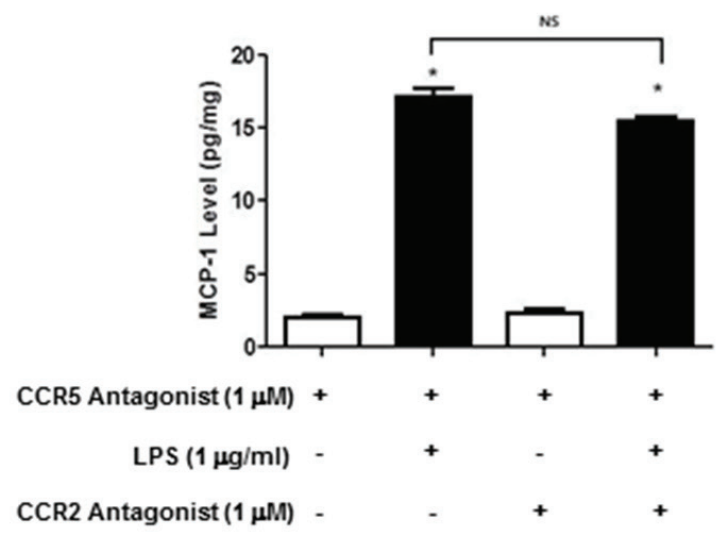

memory dysfunction, the amount of $\mathrm{A} \beta_{1-42}$ and expression of amyloidogenesis related proteins (BACE1 and APP) were much higher in the brains of LPS treated CCR5 /- mice than those of LPS treated $\mathrm{CCR}^{+/+}$mice. These results are similar, but higher extent to previous findings in LPS untreated CCR mice [16], and indicate again that the deficiency CCR5 in the LPS treated $\mathrm{CCR} 5^{-/-}$mice leads to increased $A \beta_{1-42}$ accumulation, and thus impaired memory function.

Neuroinflammation could activate astrocytes in the brain of AD patients which gradually accumulate $\mathrm{A} \beta_{1-42}$, and the amount of $A \beta_{1-42}$ correlates positively with the extent of AD pathology [26]. We and other scientists

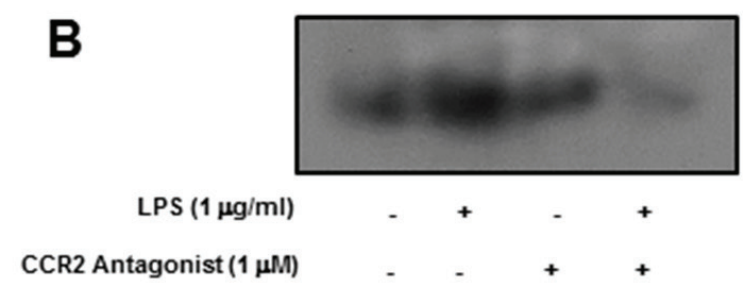

D

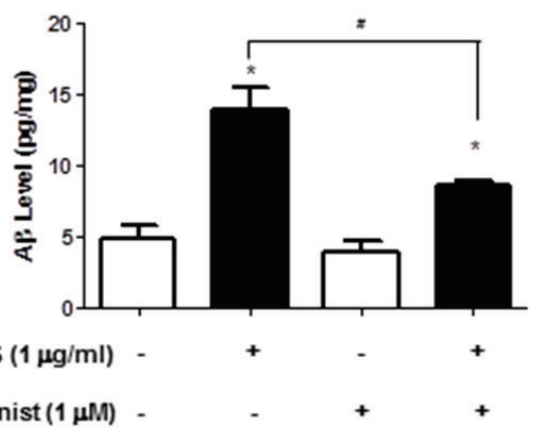

F

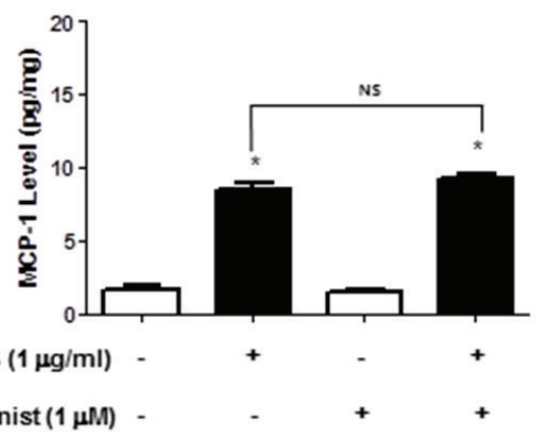

Figure 6: Activation of NF-KB and level of A $31-42$ and MCP-1 in DAPTA treated BV-2 cells and cultured astrocytes isolated from $\mathbf{C C R 5}^{-/-}$mice after CCR2 antagonist. LPS-induced Primary cultured astrocytes (isolated from CCR5 ${ }^{-/}$mice) and DAPTA treated microglial BV-2 cells were treated with CCR2 antagonist, and then activation of NF-кB was determined by EMSA A. and B. level of $A \beta_{1-42}$ was measured by using a specific $A \beta_{1-42}$ ELISA kit C. and D. MCP-1 level was measured by using a specific ELISA kit E. and F. Data are expressed as mean \pm S.E.M $(n=7)$. *Significant difference against from LPS-non treated group $(P<0.05)$ and ${ }^{\#}$ Significant difference between LPS treated groups $(P<0.05)$. 
have demonstrated that neuroinflammation induced by LPS activated astrocytes, and thus activated astrocytes generate $A \beta$ in the brain $[16,25,27,28]$. $A \beta$ accumulation in the major human cell types associated with senile plaques revealed that astrocytes generate higher levels of $A \beta[29,30]$. Moreover, recent studies have also suggested that astrocytes could act as a source for $A \beta$ because they overexpress BACE1 in response to chronic stress [8]. Our data showed that inflammation much great neuroinflamation, activation of astrocytes and $A \beta$ accumulation were found in LPS-injected $\mathrm{CCR}^{-/-}$mice compared to those in $\mathrm{CCR}^{+/+}$mice. Previously we also showed $\mathrm{CCR}^{-/}$mice activated astrocytes and induced A $\beta$ accumulation in the mice brain even without treatment of LPS [16]. Thus, these data confirmatively demonstrated that absence of CCR5 accelerates amyloidogenesis and thus, memory impairment.

In present study showed that not only phospholylation of $\mathrm{IkB}$ but also translocation of $\mathrm{p} 50$ and p65 protein in LPS-injected CCR $5^{-/}$mice. Binding capability with NF-KB was also higher in LPS-injected $\mathrm{CCR}^{-/-}$mice. NF-KB regulates pro-inflammatory cytokine expressions such as IL- 6 , IL- $1 \beta$ and TNF- $\alpha$, which are present at increased levels in the brains of $\mathrm{AD}$ patients $[31,32]$. These cytokines (IL-6 and IL-1 $\beta$ ) increase not only inflammation, but also apoptotic cell death in the brain [33]. Injections of IL- $1 \alpha$ or IL- $1 \beta$ in the brain also exhibited increased $\mathrm{AD}$ associated with plaque formation [34]. Also, the NF- $\kappa \mathrm{B}$ controls the expression of APP and BACE1, which enhances A $\beta$ formation [35]. According to these evidences, LPS injection can induce neuroinflammation and amyloidogenesis through NF-KB pathway in brain. The level of MCP-1 is upregulated in the brain during several neurodegenerative and acute diseases. MCP-1 gene is regulated by NF-KB phospholyration [36]. In primary cultured astrocytes from rat, NF-KB pathways are important for the release of proinflammatory cytokines such as IL- $1 \beta$ and TNF- $\alpha$ which can induce CCL2-stimulation [37]. Recently, it was demonstrated that LPS-injection enhanced NF-KB dependent MCP-1 gene expression in rat [38]. Neuroinflammation was also decreased after LPS injection in $\mathrm{MCP}-1^{-/}$mice [39]. In our present data showed that NF-KB activity as well as $\mathrm{NF}-\mathrm{KB}$ DNA-binding capacity is higher in $\mathrm{CCR}^{-/}$mice compared to $\mathrm{CCR}^{+/+}$mice when after LPS injection. According to high activity of NF-KB, levels of MCP-1 was also higher in LPS-injected $\mathrm{CCR} 5^{-/-}$mice than that of $\mathrm{CCR5}^{+/+}$mice. Additionaly, MCP-1 which is ligand of CCR2 was also higher in $\mathrm{CCR}^{-/}$mice compared to $\mathrm{CCR}^{+/+}$mice after LPS injection. In our previously study [16], CCR2 expression was increased close to $130 \%$ in $\mathrm{CCR}^{-/-}$mice brain compared to $\mathrm{CCR}^{+/+}$mice brain without LPS injection. However, in present study, there are about $200 \%$ increase in $\mathrm{CCR}^{-/}$mice brain compared to $\mathrm{CCR}^{+/+}$mice brain after LPS injection. Also, increase range of $A \beta$ accumulation (LPS non injection: 120\%,
LPS injection: 170\%) and neuronal cell death (LPS non injection: $120 \%$, LPS injection: $300 \%$ ) between $\mathrm{CCR}^{+/+}$ mice and $\mathrm{CCR}^{-/-}$mice were significantly expand after LPS injection. These data suggest that enhancement of activation of astrocytes may be critically implicated in the accumulation of $\mathrm{A} \beta$ and memory dysfunction in the CCR5 - mice, and it was amplified by the treatment with LPS through NF-kB pathway.

We previously also found that the extensive expression of CCR2 in the brains of $\mathrm{CCR}^{-/}$mice was higher than that of $\mathrm{CCR}^{+/+}$mice. Among the $\mathrm{CC}$ receptors, CCR2 shares one or more ligands with CCR5 [40-42], and the increased expression of CCR2 is the result of a compensating response for the absence of CCR5 [43]. A recent study revealed that chemokines such as MCP-1(CCL2) activate astrocytes via CCR2 [13]. Thus, it is possible that the increased expression of CCR 2 by compensation with CCR 5 in $\mathrm{CCR}^{-/}$mice may cause astrocyte activation, which leads to deposition of $\mathrm{A} \beta$ causing memory dysfunction $[8,25,30]$. Thus, change of specific chemokines could be significant in pathphysiological alteration in $\mathrm{CCR}^{-/}$mice. There are five known members of the monocyte chemoattractant protein (MCP) family, designated as CCL2, CCL8, CCL7, CCL13, and CCL12 (MCP-1-5, respectively). CCL2 is the most potent at activating signal transduction pathways leading to monocyte transmigration [44]. In the CNS, CCR2 expression has been reported on various cell types, including neurons, astrocytes, microglia, neural progenitor cells [45-49]. During normal conditions, expression of CCR2 seems to be at consistently low levels. CCR2 expression in astrocytes and microglia seems to be quite heterogeneous and subject to significant upregulation during an inflammatory response [50-52]. Indeed, behavioral studies have shown that mice lacking CCR2 display a macrophage recruitment in several injury and disease models [53]. Following injury to the brain, astrocytes produce CCL2 mRNA within $3 \mathrm{~h}$, before the accumulation of inflammatory mononuclear cells [10]. Interestingly, other studies have shown that CCL2signalling can affect $A \beta$ pathology in animal models of $\mathrm{AD}[24,54]$. In APP expressing transgenic mouse model, increased $\mathrm{A} \beta$ pathology accelerated expressing of CCL2 [54]. Additionally CCL2 and CCR2 expression are well reported in the many studies in conditions of nerve injury [55-58] and tissue inflammation [59]. Recently studies of human indicate that CCL2 levels are increased in the brains of AD patients, and CCL2 co-localizes with senile plaques $[60,61]$. Other study suggests that the changement of CCL2-levels in MCI patients reflect this immunological activity [62]. Recently study reports that MCP-1 levels were significantly increased in serum and brain, when 6hrs after LPS injection [39]. These studies support that CCL2 associated inflammation and microgliosis might have detrimental effects on $\mathrm{A} \beta$ metabolism. Therefore, lack of CCR5 caused CCR2 expression as a mean of 
conversely compensation mechanism leading to more amyloidogenesis and more severe impairment in CCR5 /- mice with LPS treatment.

CCR5 deficiency-mediated memory dysfunction could be related with the neuroprotective role of CCR5. Several CCR members are expressed in the CNS cell types including astrocytes and microglia [45], and their ligands such as MIP-1 $\beta$ have been found to be highly expressed in cerebrospinal fluid (CSF). It was also noteworthy that CCR5 antagonist treated neurons and glial cells cultured from rat showed less toxicity against $\mathrm{A} \beta$ as compared with cells cultured from control wild mice [63]. However, the chemokine receptor CCR5 is not a necessary inflammatory mediator in brain injury. After hippocampal injury, not only expression but also mRNA level of CCR2 and CCR3 were increased in CCR5 deficient mice compared to CCR5 wild type mice [43]. Expression of CCR2 was different between wild type and mutant type of CCR 5 mice brains, suggesting CCR2 may be affected by CCR5, and these changes could be amplified by LPS leading greater of memory dysfunction. LPS produced significantly higher levels of cytokines and chemokines, in brain for IL-1a, IL6, MCP-1, MIP-1a, and TNF and in serum for IL-6 [64]. Because of the high level of CCR2 expression, deficiency in $\mathrm{CCR}^{-/}$mice may not ensure the neuroprotective role of chemokines leading to loss the maintenance of memory function.

In addition, neuronal cell differentiation could be mediated by CCR5. Neuronal differentiation is an important factor to prevent neurodegeneration in Alzheimer's disease and related disorders [65]. In our previous study show that neuronal cell differentiation was abolished by CCR5 disruption [66].

In this study, it is notable that the cell death in the brains of $\mathrm{CCR} 5^{-/}$mice was significantly higher than in the brains of $\mathrm{CCR}^{+/+}$mice. Thus, it is also possible that the lack of CCR5 may not be sufficient to prevent neuronal cell death from elevated $\mathrm{A} \beta$ deposit. Taken together, these findings suggest that absence of CCR5 leads to accelerate LPS-induced astrocytes activation, and A $\beta$ deposition through an increase in CCR2, and can possibly result in more severe impaired memory function.

\section{MATERIALS AND METHODS}

\section{LPS induced memory impairment mouse model}

The age (4 5 month old), sex (male) and weight (26$27 \mathrm{~g})$ matched CCR5 wild type $\left(\mathrm{CCR}^{+/+}\right)$mice and CCR5 knock out $\left(\mathrm{CCR}^{-/-}\right)$mice were maintained in accordance with the guidance of the National Institute of Toxicological Research for the care and use of laboratory animals. All of the experimental procedures were approved by the Animal Care and Use Committee (IACUC) of Chungbuk National
University (approval number: CBNUA-144-1001-01). The $\mathrm{CCR}^{+/+}$and $\mathrm{CCR5}^{-/}$mice were purchased from The Jackson Laboratory (Bar Harbor, Maine 04609). $\mathrm{CCR}^{-/-}$mice have no overt developmental abnormalities. Control mice (B6129PF2/J) were F2 hybrid mice from the C57BL/6J-AW-J and 129P3/J parental strains. CCR5 1- mice (B6;129P2-Ccr5tm1Kuz/J) have the entire coding region of the CCR5 gene deleted from the parental strains, B6;129P2-Ccr5tm1 kuz and B6;129P2-Cmkbr5tm1Kuz. The LPS (Sigma, St. Louis, MO; final concentration of 0.1 $\mathrm{mg} / \mathrm{ml})$ was dissolved, and aliquots in saline were stored at $-20^{\circ} \mathrm{C}$ until use. The ip injection $(0.25 \mathrm{mg} / \mathrm{kg})$ of LPS or vehicle (saline) was administered daily for 7 days.

\section{Water maze test}

Water maze test was described by Morris et al. (1984) using the SMART-CS program and equipment (Panlab, Barcelona, Spain). A circular pool (Height: 35 $\mathrm{cm}$, Diameter: $100 \mathrm{~cm}$ ) was filled with milky water and maintained at $22 \sim 25^{\circ} \mathrm{C}$. An escape platform (Height: 14.5 $\mathrm{cm}$, Diameter: $4.5 \mathrm{~cm}$ ) was then submerged $0.5 \sim 1 \mathrm{~cm}$ below the surface of the water in the northeastern quadrant position of the pool. During testing, mice were placed in the plastic pool, allowed $60 \mathrm{sec}$ to find the hidden platform and remain on the platform for $10 \mathrm{sec}$. Mice that did not find the platform within $60 \mathrm{sec}$ were placed on the platform for $10 \mathrm{sec}$ at the end of the trial. Escape latency (the time required to find the platform), escape distance (the distance swam to find the platform), swimming speed, and swimming patterns were monitored for 8 days using a camera positioned above the counter of the pool. The camera was connected to a computer running the SMARTLD program (Panlab).

\section{Probe test}

To assess memory consolidation, a probe test was performed $48 \mathrm{hr}$ after the water maze test. For the probe test, the platform was removed from the pool and the mice were allowed to swim freely. The swimming pattern of each mouse was monitored and recorded for $60 \mathrm{~s}$ using the SMART-LD program (Panlab). Consolidated spatial memory was estimated by the time spent in the target area which adjacent to platform.

\section{Passive avoidance test (Step-through test)}

The passive avoidance test is a widely accepted simple and rapid means of memory testing. Passive avoidance response was determined using a "stepthrough" apparatus (Med Associated, St. Albans, VT, USA), which consisted of an illuminated and a dark compartment (each $20.3 \times 15.9 \times 21.3 \mathrm{~cm}$ ) adjoining each 
other through a guillotine door. Floors were constructed of $3.175 \mathrm{~mm}$ stainless steel rods set $8 \mathrm{~mm}$ apart. The test was conducted on 2 consecutive days at the same time of day. On the first day (learning trials), each mouse was placed in the illuminated compartment facing away from the dark compartment. Once the mouse enters completely into the dark compartment, it receives an electric shock $(0.5 \mathrm{~mA}, 3 \mathrm{sec})$ through the stainless steel grid floor. The time required until the mouse entered into the dark compartment was recorded automatically and described as the step-through latency. On the second day (testing day), the same test procedure was followed. When the mouse did not enter the dark compartment within $300 \mathrm{sec}$, the test was terminated and a latency of $300 \mathrm{sec}$ was recorded.

\section{Open field test}

Two days after the passive avoidance test, locomotor activity was evaluated by placing mice into an open-field arena. Each mice were individually placed in the center of the open field $(50 \times 50 \times 30 \mathrm{~cm})$ and left to explore freely for $10 \mathrm{~min}$ in standard room-lighting conditions. Activity in the plexiglas was quantitated by a computer-operated system [SMART-LD program (Panlab)]. The total distance moved in the arena in 10 min was recorded as a measure of locomotor distance. Frequency and duration of entering into a central square $(25 \mathrm{~cm} \times 25 \mathrm{~cm})$ of the open field during the 10 min were automatically recorded and were used as measures of anxiety-related behavior.

\section{Locomotor activity}

Spontaneous locomotor activity was measured automatically with a tilting-type ambulometer (AMB-10, O'Hara, Japan). Each mouse was placed in the activity cage $(20 \mathrm{~cm}$ in diameter and $18 \mathrm{~cm}$ in height) and after an adaptation period of $10 \mathrm{~min}$.

\section{Western blotting}

Brain and spinal cord tissues were homogenized with protein extraction solution (PRO-PREPTM, Intron Biotechnology, Seoul, Korea), and lysed by $60 \mathrm{~min}$ incubation on ice. The lysate centrifuged at 15,000 $\mathrm{rpm}$ for $30 \mathrm{~min}$ at $4^{\circ} \mathrm{C}$. Equal amount of protein (40 $\mu \mathrm{g})$ were separated on a SDS/10\%-olyacrylamide gel, and then transferred to a polyvinylidene difluroride (PVDF) membrane (GE Water \& Process technologies, Trevose, PA, USA). Blots were blocked for $1 \mathrm{hr}$ at room temperature with $5 \%(\mathrm{w} / \mathrm{v})$ non-fat dried milk in TrisBuffered Saline Tween-20 [TBST: $10 \mathrm{mM}$ Tris (pH 8.0) and $150 \mathrm{mM} \mathrm{NaCl}$ solution containing $0.05 \%$ tween-20]. After a short wash in TBST, the membrane was incubated at room temperature with specific antibodies. Rabbit polyclonal antibodies against APP (1:1000, Affinity BioReagents, Golden, CO, USA) and BACE1 (1:500, Sigma, St Louis, MO, USA), and gout polyclonal antibody against CCR2 (1:1000, Abcam, Cambrige, MA, USA) were used in study. The blot was then incubated with the corresponding conjugated anti-rabbit, anti-mouse and anti-gout immunoglobulin G-horseradish peroxidase (1:2000, Santa Cruz Biotechn, Santa Cruz, CA, USA). Immunoreactive proteins were detected with the BM chemiluminescence blotting substrate (Roche Applied Science, Mannheim, Germany).

\section{Immunohistochemistry}

Mice were anesthetized with ether. While under general anesthesia, the mice received intracardiac perfusion with $20 \mathrm{ml}$ of saline, followed by $50 \mathrm{ml}$ of phosphate-buffered saline (PBS) containing 4\% paraformaldehyde. After perfusion, the brain was dissected and post-fixed for 2-4 hr in the same fixative, and were then cryoprotected overnight in 30\% sucrose prepared in PBS. Serial coronal sections of brain $(40 \mu \mathrm{m})$ were cut with a freezing microtome.

Sections were rinsed in $0.1 \mathrm{M}$ phosphate buffer and treated with $3 \%$ hydrogen peroxide for $30 \mathrm{~min}$. After washing in PBS, the sections were incubated overnight at $4^{\circ} \mathrm{C}$ with antibodies specific for $\mathrm{A} \beta_{1-42}$ (1:2000, Covance, Berkely, CA) or GFAP (1:5000, Abcam), incubated in biotinylated goat anti-rabbit $\operatorname{IgG}(1: 2000$, Vector Laboratories, Burlingame, CA, USA) for $1 \mathrm{hr}$ at room temperature (RT), followed by incubation in avidinconjugated peroxidase complex (ABC, 1:200, Vector Laboratories) for $30 \mathrm{~min}$ at $\mathrm{RT}$, and the peroxidase reaction was visualized using 3, $3{ }^{`}$-diaminobenzidine tetrahydrochloride (DAB, $0.02 \%$ ) as the chromogen. The sections were rinsed, mounted on poly-glycine-coated slides, dehydrated, and cover-slipped for light microscopy and photography.

\section{Immunofluorescence}

Sections were treated with $10 \%$ bovine serum albumin in PBS for $1 \mathrm{hr}$ at RT, incubated overnight at $4^{\circ} \mathrm{C}$ with CCR2 (1:300, Goat monoclonal, R\&D Systems, Minneapolis, MN, USA) or GFAP (1:300, mouse, Santa Cruz Biotechn, Santa Cruz, CA, USA), followed by incubation in anti-mouse IgG conjugated with Alexa 488 (1:300 dilution, Molecular Probes, Eugene, OR, USA) or anti-goat IgG conjugated with Alexa 568 (1:300 dilution, Molecular Probes) for $40 \mathrm{~min}$ at RT. Finally, the sections were rinsed, mounted on slides, and cover-slipped for fluorescence microscopy and photography using ApoTome microscopy (Carl Zeiss, Thornwood, NY, USA). 


\section{Measurement of $A \beta_{1-42}$}

Lysates of brain tissue were obtained through protein extraction buffer containing protease inhibitor. $\mathrm{A} \beta_{1-42}$ levels were determined using a specific ELISA Kit (Immuno-Biological Laboratories Co., Ltd., TakasakiShi, Gunma, Japan). In brief, $100 \mu$ of sample was added into the precoated plate and was incubated overnight at $4^{\circ} \mathrm{C}$. After washing each well of the precoated plate with washing buffer, $100 \mu \mathrm{l}$ of labeled antibody solution was added and the mixture was incubated for $1 \mathrm{hr}$ at $4{ }^{\circ} \mathrm{C}$ in the dark. After washing, chromogen was added and the mixture was incubated for $30 \mathrm{~min}$ at room temperature in the dark. Finally, the resulting color was assayed at 450 $\mathrm{nm}$ using a microplate absorbance reader (SunriseTM, TECAN, Switzerland) after adding stop solution.

\section{Measurement of MCP-1}

Lysates of brain tissue were obtained through protein extraction buffer containing protease inhibitor. MCP-1 levels were determined using a specific ELISA Kit (R\&D Systems, Minneapolis, MN, USA). In brief, 100 $\mu \mathrm{l}$ of sample was added into the precoated plate and was incubated $3 \mathrm{hr}$ at room temperature. After washing each well of the precoated plate with washing buffer, $100 \mu$ of labeled antibody solution was added and the mixture was incubated for $1 \mathrm{hr}$ at room temperature. After washing, chromogen was added and the mixture was incubated for $30 \mathrm{~min}$ at room temperature in the dark. Finally, the resulting color was assayed at $450 \mathrm{~nm}$ using a microplate absorbance reader (SunriseTM, TECAN, Switzerland) after adding stop solution.

\section{Detection of cell death}

In order to investigate apoptotic cell death, immunohistochemistry for terminal deoxynucleotidyl transferase-mediated dUTP nick end-labeling (TUNEL) assay for specific apoptosis markers were performed. Alternatively, sections were submitted to the TUNEL assay at various time points to determine DNA fragmentation according to manufacturer's instructions (In Situ Cell Death Detection kit, POD, Roche). In brief, tissues were post-fixated by $4 \%$ paraformaldehyde for 30 min, and then washed by PBS. Tissues were incubated with permeabilization solution $(0.1 \%$ Triton X-100 and $0.1 \%$ sodium citrate in PBS) for $2 \mathrm{~min}$ on ice. The sections were then incubated in the mixture of labeling solution $(450 \mu \mathrm{l})$ and enzyme solution $(50 \mu \mathrm{l})$ for $1 \mathrm{hr}$ at $37^{\circ} \mathrm{C}$ and washed 3 times on $0.1 \mathrm{M}$ PBS for 5 min each according to manufacturer's instructions. Next, the sections were incubated with DAPI for $15 \mathrm{~min}$ at $37^{\circ} \mathrm{C}$. Finally, the sections were rinsed, mounted on slides, and cover-slipped for fluorescence microscopy and photography using ApoTome microscopy (Carl Zeiss).

\section{Gel electromobility shift assay (EMSA)}

Gel shift assays were performed according to the manufacturer's recommendations (Promega, Madison, WI). Briefly, $5 \times 106$ cells was washed twice with $1 \times$ PBS, followed by the addition of $1 \mathrm{ml}$ of PBS, and the cells were scraped into a cold Eppendorf tube. Cells were spun down at 13,000 rpm for $5 \mathrm{~min}$, and the resulting supernatant was removed. Cell were suspended in 400 $\mu 1$ of solution A containing $10 \mathrm{mM}$ HEPES, $\mathrm{pH} 7.9,1.5$ $\mathrm{mM} \mathrm{MgCl} 2,10 \mathrm{mM} \mathrm{KCl}, 0.5 \mathrm{mM}$ dithiothreitol, 0.2 $\mathrm{mM}$ phenylmethylsulfonyl fluoride; vigorously vortexed; allowed to incubate on ice for $10 \mathrm{~min}$; and centrifuged at $12,000 \mathrm{rpm}$ for $6 \mathrm{~min}$. The pelleted nuclei were resuspended in solution $\mathrm{C}$ (solution $\mathrm{A}+420 \mathrm{mM} \mathrm{NaCl}$, $20 \%$ glycerol) and allowed to incubate on ice for $20 \mathrm{~min}$. The cells were centrifuged at 15,000 rpm for $15 \mathrm{~min}$, and the resulting nuclear extract supernatant was collected in a chilled Eppendorf tube. Consensus oligonucleotides were end-labeled using T4 polynucleotide kinase and $[\gamma-32 \mathrm{P}]$ ATP for $10 \mathrm{~min}$ at $37^{\circ} \mathrm{C}$. Gel shift reactions were assembled and allowed to incubate at room temperature for $10 \mathrm{~min}$ followed by the addition of $1 \mu 1(50,000-200,000$ $\mathrm{cpm}$ ) of 32P end-labeled oligonucleotide and another 20 min of incubation at room temperature. Subsequently 1 $\mu l$ of gel loading buffer was added to each reaction and loaded onto a $6 \%$ nondenaturing gel and electrophoresis until the dye was four-fifths of the way down the gel. The gel was dried at $80{ }^{\circ} \mathrm{C}$ for $1 \mathrm{hr}$ and exposed to film overnight at $-70^{\circ} \mathrm{C}$.

\section{Astrocytes cells culture}

Astrocytes were prepared from the cerebral cortex of 1-day-old neonatal rat. The cerebral cortex was dissociated into a single-cell suspension by trypsinization and mechanical disruption. The cells were seeded on PLL $(0.1 \mathrm{mg} / \mathrm{ml}$, Sigma) coated culture flasks and incubated in Dulbecco's modified eagle medium (DMEM)/F-12 (Invitrogen, Carlsbad, CA) containing 5\% fetal bovine serum (FBS) (Invitrogen). The culture medium was replaced at $24 \mathrm{~h}$ and every 3 days thereafter. After 1012 days, the cultures became confluent and loosely attached microglia and oligodendrocyte precursor cells were removed from the cell monolayer. Astrocytes were subsequently detached using trypsin-EDTA and plated into PLL-coated 6-well plates. 


\section{Statistics}

Data in Figure 1B and 1C were analyzed by twoway ANOVA, and all other data were analyzed using ANOVA followed by Dunnett's post hoc tests using GraphPad Prism 4 software (Version 4.03, GraphPad software, Inc.).. The level of significance was set at $P<$ 0.05 .

\section{ACKNOWLEDGMENTS}

This work was supported by a grant from the National Research Foundation of Korea (NRF) funded by the Korean Government (MSIP; MRC, 2008-0062275), by a grant from Marine Biotechnology Program (20150184) from the Ministry of Oceans and Fisheries, Korea.

\section{CONFLICTS OF INTEREST}

The authors declare no competing financial interests.

\section{REFERENCES}

1. Dickson DW. The pathogenesis of senile plaques. Journal of neuropathology and experimental neurology. 1997; 56:321339.

2. Oakley H, Cole SL, Logan S, Maus E, Shao P, Craft J, Guillozet-Bongaarts A, Ohno M, Disterhoft J, Van Eldik L, Berry $\mathrm{R}$ and Vassar R. Intraneuronal betaamyloid aggregates, neurodegeneration, and neuron loss in transgenic mice with five familial Alzheimer's disease mutations: potential factors in amyloid plaque formation. The Journal of neuroscience. 2006; 26:10129-10140.

3. Scheff SW and Price DA. Synaptic density in the inner molecular layer of the hippocampal dentate gyrus in Alzheimer disease. Journal of neuropathology and experimental neurology. 1998; 57:1146-1153.

4. Selkoe DJ. Alzheimer's disease: genes, proteins, and therapy. Physiological reviews. 2001; 81:741-766.

5. Utsuki T, Yu QS, Davidson D, Chen D, Holloway HW, Brossi A, Sambamurti K, Lahiri DK, Greig NH and Giordano T. Identification of novel small molecule inhibitors of amyloid precursor protein synthesis as a route to lower Alzheimer's disease amyloid-beta peptide. The Journal of pharmacology and experimental therapeutics. 2006; 318:855-862.

6. Kurt MA, Davies DC and Kidd M. beta-Amyloid immunoreactivity in astrocytes in Alzheimer's disease brain biopsies: an electron microscope study. Experimental neurology. 1999; 158:221-228.

7. Nagele RG, D'Andrea MR, Lee H, Venkataraman V and Wang HY. Astrocytes accumulate A beta 42 and give rise to astrocytic amyloid plaques in Alzheimer disease brains. Brain research. 2003; 971:197-209.
8. Rossner S, Lange-Dohna C, Zeitschel U and Perez-Polo JR. Alzheimer's disease beta-secretase BACE1 is not a neuronspecific enzyme. Journal of neurochemistry. 2005; 92:226234.

9. Dorf ME, Berman MA, Tanabe S, Heesen M and Luo Y. Astrocytes express functional chemokine receptors. Journal of neuroimmunology. 2000; 111:109-121.

10. Glabinski AR, Balasingam V, Tani M, Kunkel SL, Strieter RM, Yong VW and Ransohoff RM. Chemokine monocyte chemoattractant protein-1 is expressed by astrocytes after mechanical injury to the brain. Journal of immunology. 1996; 156:4363-4368.

11. Xia MQ and Hyman BT. Chemokines/chemokine receptors in the central nervous system and Alzheimer's disease. Journal of neurovirology. 1999; 5:32-41.

12. Ishizuka K, Igata-Yi R, Kimura T, Hieshima K, Kukita T, Kin Y, Misumi Y, Yamamoto M, Nomiyama H, Miura R, Takamatsu J, Katsuragi S and Miyakawa T. Expression and distribution of $\mathrm{CC}$ chemokine macrophage inflammatory protein-1 alpha/LD78 in the human brain. Neuroreport. 1997; 8:1215-1218.

13. Quinones MP, Kalkonde Y, Estrada CA, Jimenez F, Ramirez R, Mahimainathan L, Mummidi S, Choudhury GG, Martinez H, Adams L, Mack M, Reddick RL, Maffi S, Haralambous S, Probert L, Ahuja SK, et al. Role of astrocytes and chemokine systems in acute TNFalpha induced demyelinating syndrome: CCR2-dependent signals promote astrocyte activation and survival via NF-kappaB and Akt. Molecular and cellular neurosciences. 2008; 37:96-109.

14. Simard AR, Soulet D, Gowing G, Julien JP and Rivest $\mathrm{S}$. Bone marrow-derived microglia play a critical role in restricting senile plaque formation in Alzheimer's disease. Neuron. 2006; 49:489-502.

15. Stalder AK, Ermini F, Bondolfi L, Krenger W, Burbach GJ, Deller T, Coomaraswamy J, Staufenbiel M, Landmann R and Jucker M. Invasion of hematopoietic cells into the brain of amyloid precursor protein transgenic mice. The Journal of neuroscience. 2005; 25:11125-11132.

16. Lee YK, Kwak DH, Oh KW, Nam SY, Lee BJ, Yun YW, Kim YB, Han SB and Hong JT. CCR5 deficiency induces astrocyte activation, Abeta deposit and impaired memory function. Neurobiology of learning and memory. 2009; 92:356-363.

17. Shaw KN, Commins S and O'Mara SM. Lipopolysaccharide causes deficits in spatial learning in the watermaze but not in BDNF expression in the rat dentate gyrus. Behavioural brain research. 2001; 124:47-54.

18. Sparkman NL, Martin LA, Calvert WS and Boehm GW. Effects of intraperitoneal lipopolysaccharide on Morris maze performance in year-old and 2-month-old female C57BL/6J mice. Behavioural brain research. 2005; 159:145-151.

19. Machado RR, Soares DM, Proudfoot AE and Souza GE. 
CCR1 and CCR5 chemokine receptors are involved in fever induced by LPS (E. coli) and RANTES in rats. Brain research. 2007; 1161:21-31.

20. Spleiss O, Appel K, Boddeke HW, Berger M and GebickeHaerter PJ. Molecular biology of microglia cytokine and chemokine receptors and microglial activation. Life sciences. 1998; 62:1707-1710.

21. Gamo K, Kiryu-Seo S, Konishi H, Aoki S, Matsushima K, Wada K and Kiyama H. G-protein-coupled receptor screen reveals a role for chemokine receptor CCR5 in suppressing microglial neurotoxicity. The Journal of neuroscience. 2008; 28:11980-11988.

22. Gramegna P, Latronico T, Brana MT, Di Bari G, Mengoni F, Belvisi V, Mascellino MT, Lichtner M, Vullo V, Mastroianni CM and Liuzzi GM. In vitro downregulation of matrix metalloproteinase-9 in rat glial cells by CCR5 antagonist maraviroc: therapeutic implication for HIV brain infection. PloS one. 2011; 6:e28499.

23. Engeland CG, Nielsen DV, Kavaliers M and Ossenkopp KP. Locomotor activity changes following lipopolysaccharide treatment in mice: a multivariate assessment of behavioral tolerance. Physiology \& behavior. 2001; 72:481-491.

24. Kiyota T, Yamamoto M, Xiong H, Lambert MP, Klein WL, Gendelman HE, Ransohoff RM and Ikezu T. CCL2 accelerates microglia-mediated Abeta oligomer formation and progression of neurocognitive dysfunction. PloS one. 2009; 4:e6197.

25. Busciglio J, Gabuzda DH, Matsudaira P and Yankner BA. Generation of beta-amyloid in the secretory pathway in neuronal and nonneuronal cells. Proceedings of the National Academy of Sciences of the United States of America. 1993; 90:2092-2096.

26. Cummings BJ, Pike CJ, Shankle R and Cotman CW. Betaamyloid deposition and other measures of neuropathology predict cognitive status in Alzheimer's disease. Neurobiology of aging. 1996; 17:921-933.

27. Kim JA, Yun HM, Jin P, Lee HP, Han JY, Udumula V, Moon DC, Han SB, Oh KW, Ham YW, Jung HS, Song HS and Hong JT. Inhibitory effect of a 2,4-bis(4hydroxyphenyl)-2-butenal diacetate on neuro-inflammatory reactions via inhibition of STAT1 and STAT3 activation in cultured astrocytes and microglial BV-2 cells. Neuropharmacology. 2014; 79:476-487.

28. Song SY, Jung YY, Hwang CJ, Lee HP, Sok CH, Kim JH, Lee SM, Seo HO, Hyun BK, Choi DY, Han SB, Ham YW, Hwang BY and Hong JT. Inhibitory effect of entSauchinone on amyloidogenesis via inhibition of STAT3mediated NF-kappaB activation in cultured astrocytes and microglial BV-2 cells. Journal of neuroinflammation. 2014; $11: 118$.

29. Oberstein TJ, Spitzer P, Klafki HW, Linning P, Neff F, Knolker HJ, Lewczuk P, Wiltfang J, Kornhuber J and Maler JM. Astrocytes and microglia but not neurons preferentially generate N-terminally truncated Abeta peptides. Neurobiology of disease. 2015; 73:24-35.
30. LeBlanc AC, Papadopoulos M, Belair C, Chu W, Crosato $\mathrm{M}$, Powell J and Goodyer CG. Processing of amyloid precursor protein in human primary neuron and astrocyte cultures. Journal of neurochemistry. 1997; 68:1183-1190.

31. Griffin WS, Stanley LC, Ling C, White L, MacLeod V, Perrot LJ, White CL, 3rd and Araoz C. Brain interleukin 1 and S-100 immunoreactivity are elevated in Down syndrome and Alzheimer disease. Proceedings of the National Academy of Sciences of the United States of America. 1989; 86:7611-7615.

32. Steinman L. Nuanced roles of cytokines in three major human brain disorders. The Journal of clinical investigation. 2008; 118:3557-3563.

33. Rahman SM, Van Dam AM, Schultzberg M and Crisby M. High cholesterol diet results in increased expression of interleukin- 6 and caspase- 1 in the brain of apolipoprotein E knockout and wild type mice. Journal of neuroimmunology. 2005; 169:59-67.

34. Sheng JG, Ito $\mathrm{K}$, Skinner RD, Mrak RE, Rovnaghi $\mathrm{CR}$, Van Eldik LJ and Griffin WS. In vivo and in vitro evidence supporting a role for the inflammatory cytokine interleukin-1 as a driving force in Alzheimer pathogenesis. Neurobiology of aging. 1996; 17:761-766.

35. Sambamurti K, Kinsey R, Maloney B, Ge YW and Lahiri DK. Gene structure and organization of the human betasecretase (BACE) promoter. FASEB J. 2004; 18:10341036.

36. Teferedegne B, Green MR, Guo Z and Boss JM. Mechanism of action of a distal NF-kappaB-dependent enhancer. Molecular and cellular biology. 2006; 26:5759-5770.

37. Thompson WL and Van Eldik LJ. Inflammatory cytokines stimulate the chemokines CCL2/MCP-1 and CCL7/MCP3 through NFkB and MAPK dependent pathways in rat astrocytes [corrected]. Brain research. 2009; 1287:47-57.

38. Wang Y, Rangan GK, Goodwin B, Tay YC and Harris DC. Lipopolysaccharide-induced MCP-1 gene expression in rat tubular epithelial cells is nuclear factor-kappaB dependent. Kidney international. 2000; 57:2011-2022.

39. Thompson WL, Karpus WJ and Van Eldik LJ. MCP-1deficient mice show reduced neuroinflammatory responses and increased peripheral inflammatory responses to peripheral endotoxin insult. Journal of neuroinflammation. 2008; 5:35.

40. Bajetto A, Bonavia R, Barbero S, Florio T and Schettini G. Chemokines and their receptors in the central nervous system. Frontiers in neuroendocrinology. 2001; 22:147-184.

41. de Paulis A, Annunziato F, Di Gioia L, Romagnani S, Carfora M, Beltrame C, Marone G and Romagnani P. Expression of the chemokine receptor CCR3 on human mast cells. International archives of allergy and immunology. 2001; 124:146-150.

42. Romagnani S. Cytokines and chemoattractants in allergic inflammation. Molecular immunology. 2002; 38:881-885.

43. Chen Z, Yu S, Bakhiet M, Winblad B and Zhu J. The 
chemokine receptor CCR5 is not a necessary inflammatory mediator in kainic acid-induced hippocampal injury: evidence for a compensatory effect by increased CCR2 and CCR3. Journal of neurochemistry. 2003; 86:61-68.

44. Sozzani S, Zhou D, Locati M, Rieppi M, Proost P, Magazin M, Vita N, van Damme J and Mantovani A. Receptors and transduction pathways for monocyte chemotactic protein-2 and monocyte chemotactic protein-3. Similarities and differences with MCP-1. Journal of immunology. 1994; 152:3615-3622.

45. Banisadr G, Gosselin RD, Mechighel P, Rostene W, Kitabgi $\mathrm{P}$ and Melik Parsadaniantz S. Constitutive neuronal expression of CCR2 chemokine receptor and its colocalization with neurotransmitters in normal rat brain: functional effect of MCP-1/CCL2 on calcium mobilization in primary cultured neurons. The Journal of comparative neurology. 2005; 492:178-192.

46. Banisadr G, Queraud-Lesaux F, Boutterin MC, Pelaprat D, Zalc B, Rostene W, Haour F and Parsadaniantz SM. Distribution, cellular localization and functional role of CCR2 chemokine receptors in adult rat brain. Journal of neurochemistry. 2002; 81:257-269.

47. Coughlan CM, McManus CM, Sharron M, Gao Z, Murphy D, Jaffer S, Choe W, Chen W, Hesselgesser J, Gaylord H, Kalyuzhny A, Lee VM, Wolf B, Doms RW and Kolson DL. Expression of multiple functional chemokine receptors and monocyte chemoattractant protein-1 in human neurons. Neuroscience. 2000; 97:591-600.

48. Gourmala NG, Buttini M, Limonta S, Sauter A and Boddeke HW. Differential and time-dependent expression of monocyte chemoattractant protein-1 mRNA by astrocytes and macrophages in rat brain: effects of ischemia and peripheral lipopolysaccharide administration. Journal of neuroimmunology. 1997; 74:35-44.

49. Stamatovic SM, Shakui P, Keep RF, Moore BB, Kunkel SL, Van Rooijen N and Andjelkovic AV. Monocyte chemoattractant protein-1 regulation of blood-brain barrier permeability. Journal of cerebral blood flow and metabolism. 2005; 25:593-606.

50. Andjelkovic AV, Song L, Dzenko KA, Cong $\mathrm{H}$ and Pachter JS. Functional expression of CCR 2 by human fetal astrocytes. Journal of neuroscience research. 2002; 70:219231.

51. Croitoru-Lamoury J, Guillemin GJ, Boussin FD, Mognetti B, Gigout LI, Cheret A, Vaslin B, Le Grand R, Brew BJ and Dormont D. Expression of chemokines and their receptors in human and simian astrocytes: evidence for a central role of TNF alpha and IFN gamma in CXCR4 and CCR5 modulation. Glia. 2003; 41:354-370.

52. White FA, Sun J, Waters SM, Ma C, Ren D, Ripsch M, Steflik J, Cortright DN, Lamotte RH and Miller RJ. Excitatory monocyte chemoattractant protein-1 signaling is up-regulated in sensory neurons after chronic compression of the dorsal root ganglion. Proceedings of the National Academy of Sciences of the United States of America.
2005; 102:14092-14097.

53. Goser S, Ottl R, Brodner A, Dengler TJ, Torzewski J, Egashira K, Rose NR, Katus HA and Kaya Z. Critical role for monocyte chemoattractant protein-1 and macrophage inflammatory protein-1alpha in induction of experimental autoimmune myocarditis and effective anti-monocyte chemoattractant protein-1 gene therapy. Circulation. 2005; 112:3400-3407.

54. Yamamoto M, Horiba M, Buescher JL, Huang D, Gendelman HE, Ransohoff RM and Ikezu T. Overexpression of monocyte chemotactic protein-1/CCL2 in beta-amyloid precursor protein transgenic mice show accelerated diffuse beta-amyloid deposition. The American journal of pathology. 2005; 166:1475-1485.

55. Jung H, Toth PT, White FA and Miller RJ. Monocyte chemoattractant protein-1 functions as a neuromodulator in dorsal root ganglia neurons. Journal of neurochemistry. 2008; 104:254-263.

56. Tanaka T, Minami M, Nakagawa T and Satoh M. Enhanced production of monocyte chemoattractant protein-1 in the dorsal root ganglia in a rat model of neuropathic pain: possible involvement in the development of neuropathic pain. Neuroscience research. 2004; 48:463-469.

57. Thacker MA, Clark AK, Bishop T, Grist J, Yip PK, Moon LD, Thompson SW, Marchand F and McMahon SB. CCL2 is a key mediator of microglia activation in neuropathic pain states. European journal of pain. 2009; 13:263-272.

58. Zhang $J$ and De Koninck Y. Spatial and temporal relationship between monocyte chemoattractant protein-1 expression and spinal glial activation following peripheral nerve injury. Journal of neurochemistry. 2006; 97:772-783.

59. Jeon SM, Lee KM, Park ES, Jeon YH and Cho HJ. Monocyte chemoattractant protein-1 immunoreactivity in sensory ganglia and hindpaw after adjuvant injection. Neuroreport. 2008; 19:183-186.

60. Galimberti D, Schoonenboom N, Scarpini E, Scheltens P and Dutch-Italian Alzheimer Research G. Chemokines in serum and cerebrospinal fluid of Alzheimer's disease patients. Annals of neurology. 2003; 53:547-548.

61. Sokolova A, Hill MD, Rahimi F, Warden LA, Halliday GM and Shepherd CE. Monocyte chemoattractant protein-1 plays a dominant role in the chronic inflammation observed in Alzheimer's disease. Brain pathology. 2009; 19:392-398.

62. Westin $\mathrm{K}$, Buchhave $\mathrm{P}$, Nielsen $\mathrm{H}$, Minthon L, Janciauskiene S and Hansson O. CCL2 is associated with a faster rate of cognitive decline during early stages of Alzheimer's disease. PloS one. 2012; 7:e30525.

63. Kaul M, Ma Q, Medders KE, Desai MK and Lipton SA. HIV-1 coreceptors CCR5 and CXCR4 both mediate neuronal cell death but CCR5 paradoxically can also contribute to protection. Cell death and differentiation. 2007; 14:296-305.

64. Erickson MA and Banks WA. Cytokine and chemokine responses in serum and brain after single and repeated 
injections of lipopolysaccharide: multiplex quantification with path analysis. Brain, behavior, and immunity. 2011; 25:1637-1648.

65. Arendt T. Dysregulation of neuronal differentiation and cell cycle control in Alzheimer's disease. Journal of neural transmission Supplementum. 2002; 62:77-85.

66. Park MH, Lee YK, Lee YH, Kim YB, Yun YW, Nam SY, Hwang SJ, Han SB, Kim SU and Hong JT. Chemokines released from astrocytes promote chemokine receptor 5-mediated neuronal cell differentiation. Experimental cell research. 2009; 315:2715-2726. 